\author{
SoTEL Symposium 19-20 February 2020
}

\title{
Introducing Immersive Reality into the Journalism Curriculum.
}

\author{
Helen Sissons \\ Auckland University of Technology \\ helen.sissons@aut.ac.nz \\ Thomas Cochrane \\ Auckland University of Technology \\ thomas.cochrane@aut.ac.nz
}

Submission Type: Case Study (20mins + 10minsQ\&A)

Keywords: Virtual Reality, Immersive Reality, Heutagogy, Collaborative curriculum design

\begin{abstract}
:
Following the introduction of the Google Cardboard virtual reality (VR) head mounted display (HMD) in 2014, mainstream journalism began exploring the potential of VR to transform news storytelling as an immersive experience (Lalwani, 2015; Somaiya, 2015). However, unlike the transformative impact of social media on journalism and journalism education (Mulrennan, 2017), VR has taken several years for this to filter into the curriculum of journalism higher education.
\end{abstract}

AUT's journalism programme includes a final semester, capstone, assessment in which students produce a piece of long-form immersive journalism that provides the opportunity to embed VR storytelling as an authentic immersive experience. To address this we created a collaborative curriculum design team in 2019 to design a workshop (Sissons \& Cochrane, 2019) to introduce journalism students to the potential of VR to explore and create an immersive journalism experience.

We used a design based research methodology (McKenney \& Reeves, 2019) to structure the curriculum design process into four phases: initial analysis and exploration, development of a prototype curriculum intervention, evaluation and redesign of the intervention, and dissemination of identified design principles and findings. Meeting weekly the design team brainstormed a workshop that mapped the affordances of mobile XR to a real world project, and created a simple demonstration XR environment (https://seekbeak.com/v/kvPq47DpjAw). We founded the workshop design upon the principles of heutagogy (Blaschke \& Hase, 2019), as the principles of heutagogy map closely to the core journalism graduate profile outcomes (Cochrane, Sissons, \& Mulrennan, 2017). In this workshop students worked in teams to film and compile an interactive experience based on the University's Journalism Media Centre, creating an interactive tour using SeekBeak (https://seekbeak.com). Using AUTEC ethics processes we obtained informed consent from the participating students for a feedback survey that will inform the second phase redesign of the curriculum design for 2020. Anonymous postworkshop student feedback survey responses, with a $78 \%$ return rate (https://www.surveymonkey.com/results/SM-5SMVCVSJ7/) were very positive.

This presentation will overview the collaborative curriculum design approach utilised, that provides a simple model that can be utilised in other higher education discipline contexts. We will also demonstrate examples of the VR environments created by the students, and reflect upon the impact of the XR experience on student learning.

\section{References}

Blaschke, L. M., \& Hase, S. (2019). Heutagogy and digital media networks: Setting students on the path to lifelong learning. Pacific Journal of Technology Enhanced Learning, 1(1), 1-14. doi:https://doi.org/10.24135/pjtel.v1i1.1 
Cochrane, T., Sissons, H., \& Mulrennan, D. (2017). Mainstreaming Mobile Learning in Journalism Education. In H. Crompton \& J. Traxler (Eds.), Mobile Learning in Higher Education: Challenges in Context (pp. 19-30). New York: Routledge.

Lalwani, M. (2015). ABC News introduces VR initiative with 360-degree tour of Syria. Retrieved from http://www.engadget.com/2015/09/17/abc-news-introduces-vr-initiative-with-360-degree-tour-of-syria/

McKenney, S., \& Reeves, T. (2019). Conducting educational design research (2nd ed.). London: Routledge.

Mulrennan, D. (2017). Mobile Social Media and the News: Where Heutagogy Enables Journalism Education. Journalism \& Mass Communication Educator, OnlineFirst(0), 1-12. doi:10.1177/1077695817720762

Sissons, H., \& Cochrane, T. (2019). Newsroom Production: XRJournalism Workshop. Retrieved from https://tinyurl.com/XRJournalism

Somaiya, R. (2015, 20 October 2015). The Times partners with Google on virtual reality project. Retrieved from http://www.nytimes.com/2015/10/21/business/media/the-times-partners-with-google-on-virtual-realityproject.html?smid=tw-nytimestech\&smtyp $=$ cur\& $\mathrm{r}=1$ 